\title{
ŽINDYMAS IR PSICHIKĄ VEIKIANTYS VAISTAI
}

\author{
Vilius Rutkauskas $^{1}$, Sigita Lesinskiené ${ }^{2}$, Natalja Fatkulina ${ }^{3}$
}

\section{1,2Vilniaus universiteto Medicinos fakulteto Klinikinès medicinos instituto Psichiatrijos klinika, ${ }^{I}$ Respublikinès Vilniaus psichiatrijos ligoninès Universitetinis ir psichosocialinès reabilitacijos skyrius, ${ }^{3}$ Vilniaus universiteto Medicinos fakulteto Sveikatos mokslu institutas}

Raktažodžiai: žindymas, psichikos ligos, psichiką veikiantys vaistai, antidepresantai, benzodiazepinai, litis, nuotaikos stabilizatoriai.

\section{Santrauka}

Straipsnyje nagrinèjami aktualūs kūdikių žindymo ir motinu gydymo psichiką veikiančiais vaistais klausimai. Apžvelgtos pagrindinès psichotropinių vaistų grupès, pateikiamos rekomendacijos. Daugelis psichiatrinèms būklèms gydyti skiriamų vaistų laikomi pakankamai saugiais, kad motinai galima būtų rekomenduoti tęsti žindymą, nepaisant reguliaraus jų vartojimo. Psichikos sutrikimų turinčias motinas svarbu paskatinti žindyti kūdikị, kadangi tai padeda palaikyti motinos ir vaiko ryši, kuris yra svarbus sklandžiai kūdikio raidai. Dalis psichikos ligomis sergančių pacienčių atsisako tęsti žindymą arba nutraukia psichotropinių vaistų vartojimą, bijodamos pakenkti kūdikiui, todèl svarbu informuoti šeimą apie galimą riziką ir pasirinkti tinkamą vaistą. Něštumas ir gimdymas didina psichikos ligų paūmejjimo riziką, todèl siekiant užtikrinti motinos ir kūdikio sveikatą, svarbu, kad būtų skiriamas tinkamas farmakologinis ir kompleksinis nefarmakologinis gydymas. Žindymo nauda nusveria galimą riziką, jei motinos farmakologinis gydymas yra individualizuojamas, reguliariai vertinama žindomo kūdikio būklè, pacientès ir kūdikio priežiūroje sistemingai dalyvauja tarpdisciplininè specialistų komanda (psichiatras, neonatologas, akušeris, pediatras, šeimos gydytojas, klinikinis farmakologas, slaugytojas). Motinų psichikos sutrikimų paūmèjimas sukelia didelę žalą jų kūdikių raidai, todèl sprendžiant žindymo klausimus, būtina remtis moksliniais duomenimis, tinkamai informuoti visuomenę.

\section{Ivadas}

Žindymas svarbus ir fizinei, ir emocinei kūdikio raidai.
Pasaulinès sveikatos organizacijos rekomendacijos vienareikšmiškai rekomenduoja maitinti krūtimi ne mažiau kaip 6 mènesius [1]. Psichikos sutrikimų turinčias motinas svarbu paskatinti žindyti kūdikị, kadangi tai padeda palaikyti motinos ir vaiko ryši, kuris yra svarbus sklandžiam kūdikio vystymuisi. Dalis psichikos ligomis sergančių pacienčių atsisako tęsti žindymą arba nutraukia psichotropinių vaistų vartojimą, bijodamos pakenkti kūdikiui, todèl svarbu informuoti šeimą apie galimą riziką ir pasirinkti tinkamą vaistą. Daugelis psichiatrinėms būklèms gydyti skiriamų vaistų laikomi pakankamai saugiais, kad motinai galima būtų rekomenduoti tęsti žindymą, nepaisant reguliaraus jų vartojimo. Vaisto dalis, tenkanti žindomam kūdikiui, literatūroje vadinama santykine kūdikio doze (angl. RID - relative infant dose). Šis rodiklis apibūdina, kokią procentinę dalį vaisto miligramais kilogramui kūno masès gauna žindomas kūdikis. Paprastai vaistas laikomas saugiu vartoti žindymo metu tada, kai jo RID yra žemiau 10 proc. [2,3]. Atkreiptinas dèmesys, kad didelès apimties klinikinių studijų šia tematika yra itin nedaug, o pateikiama informacija dažniausiai paremta pavienių klinikinių atvejų aprašymais. Šiame straipsnyje surinkti ir apibendrinti moksliniai duomenys apie dažniausiai psichiatrijoje skiriamus vaistus ir jų poveikị žindymo saugumui. Santykinai nedidelès dalies tokių vaistų vartojimas vertinamas kaip labiau potencialiai žalingas kūdikio sveikatai, nei žindymo nauda. Tinkamas pacientų ir medikų informavimas reikalingas mažinant visuomenejje paplitusias moksliniais duomenimis nepagrịstas išankstines neigiamas nuomones apie psichotropinių vaistų vartojimą ir motinystę, dažnai neįvertinant motinų psichikos sutrikimų paūmèjimo keliamos žalos jų kūdikių raidai.

Darbo tikslas - apžvelgti naujausią literatūrą apie žindymo saugumą kūdikiui, žindančiai motinai vartojant psichiką veikiančius vaistus.

\section{Tyrimo objektas ir metodai}

Apžvelgti ir išanalizuoti literatūros šaltiniai. Publikaciju 
paieška vykdyta duomenų bazèje Pubmed. I I apžvalgą įtrauktos tik anglų kalba paskelbtos publikacijos, atitinkančios apžvelgiamą temą. İtraukti straipsniai, publikuoti ne vèliau kaip 2019 m. lapkričio 15 dieną.

\section{Tyrimo rezultatai}

Antidepresantai. Žinoma, kad depresija sergančios gimdyvès dažniau pagimdo anksčiau termino, naujagimiai būna mažesnès kūno masès [4], depresija sirgusių motinų vaikų kraujyje nustatomos didesnès kortizolio koncentracijos [5,6]. Negydoma depresija yra vienas aiškiausių rizikos faktorių pogimdyminei depresijai išsivystyti [7]. Pogimdyminè depresija turi neigiamą poveikį tiek vaiko IQ, emociniam ir kalbos vystymuisi, tiek motinos naudojamoms auklejjimo ir saugumo užtikrinimo praktikoms $[8,9]$. Pasikartojančiu depresiniu ar bipoliniu sutrikimu sergančių moterų atkryčio rizika, nutraukus medikamentinį gydymą, siekia daugiau nei 70 proc. $[10,11]$. Pogimdyminès depresijos paplitimas yra iki 13 proc. motinų, dalis jų yra gydomos antidepresantais. Didelè dalis antidepresantus vartojančių motinų pageidauja tęsti žindymą net ir vartodamos antidepresantus, bet išsamių studijų apie skirtingų antidepresantų koncentracijas motinos plazmoje, piene ar žindomo kūdikio plazmoje yra nedaug [12]. Didžioji dalis šaltinių, kuriais remiamasi vertinant antidepresantų skyrimo néštumo metu saugumą, yra pavieniai klinikiniai atvejai ar jų serijos. Studijų, kuriose yra vertinamos ir kontrolinès grupès, itin mažai. Daugeliui antidepresantų neatlikta patikimų studijų, tad jų ekskrecija ị motinos pieną ir poveikis žindomo kūdikio sveikatai nèra aiškus. Nors SNRI grupės antidepresantų saugumas ir nustatoma koncentracija motinos piene yra panašūs kaip SSRI grupès antidepresantų, jie vertinami kaip antro pasirinkimo antidepresantų grupė dèl patikimų tyrimų trūkumo [13]. SNRI grupés antidepresantas venlafaksinas patenka ị motinos pieną, nedidelès jo koncentracijos buvo aptiktos žindomų kūdikių kraujyje, vis dèlto poveikio šių vaikų sveikatai nekonstatuota [14]. Kito SNRI grupès antidepresanto duloksetino koncentracija piene taip pat nedidelè ir duomenų apie rimtą šalutinị poveikį žindomam kūdikiui nėra [13]. Dẻl patikimų duomenų trūkumo apie žindymo saugumą vartojant NaSSA grupès antidepresantus (pavyzdžiui, mianseriną, mirtazapiną), rekomenduojama šių vaisų žindančioms moterims neskirti. Daugelio triciklių antidepresantų (pavyzdžiui, amitriptilino, klomipramino, impiramino) RID siekia apie 1-3 proc. Duomenų apie rimtus sveikatos sutrikimus, pasireiškusius šios grupès vaistus vartojusių motinų žindomiems kūdikiams, nèra [2]. Remiantis šiuo metu turimais duomenimis, daugelyje šaltinių SSRI grupès antidepresantai yra laikomi saugiausiais vartoti žindymo metu. Šios grupès antidepresantai yra dažniausiai skiriami něščioms ir žindančioms motinoms.
Nors jie išsiskiria į motinos pieną, jų koncentracijos paprastai būna nežymios ir žindomam kūdikiui nepakenkia. Sertralinas ir paroksetinas laikomi saugiausiais antidepresantais ir yra rekomenduojami kaip pirmo pasirinkimo antidepresantai žindymo metu. Autoriai pateikia pavienius klinikinius atvejus, kai fluoksetinas ir citalopramas sukèlè simptomus žindomiems kūdikiams. Fluoksetino koncentracija motinos piene yra didžiausia tarp visų SSRI grupės antidepresantų. Apie esciatlopramo ir fluvoksamono saugumą žindymo metu duomenų apskritai yra mažai, todèl rekomenduojama šių antidepresantų žindymo metu esant galimybei nevartoti arba rinktis maitinimą mišiniais. Dèl duomenų trūkumo taip pat nerekomenduojama žindymo metu rinktis kitų klasių antidepresantų: agomelatino, vortioksetino [2,13,15-17]. Daugelis autorių dèl antidepresanto vartojimo rekomenduoja spręsti individualiai, bet jei nèštumo metu buvo vartotas konkretus antidepresantas ir ji vartojant psichikos būsena buvo stabili, žindymo metu tikslinga vartoti tą patị vaistą. Jei antidepresantas skirtinas jau po gimdymo ir pacientei pradejjus žindymą, pasirinktinas pirmo pasirinkimo antidepresantas - sertralinas ar paroksetinas [13].

Benzodiazepinai. Benzodiazepinų grupès vaistai skiriami tiek sunkių psichiatrinių būklių metu (pavyzdžiui, paranoidinès šizofrenijos paūmèjimas, manijos būsena ar sunki depresija) kaip papildomas gydymas ūmios būklès metu, tiek trumpalaikiam nerimo ar nemigos gydymui, nesant sunkaus psichikos sutrikimo. Jų vartojimas žindymo metu nerekomenduojamas, bet nèra absoliučiai kontraindikuotinas, jei žindomas kūdikis sveikas ir neturi ịgimtų metabolizmo sutrikimų. Vis dèlto siekiant sumažinti jų neigiamo poveikio kūdikiui riziką, rekomenduojama skirti trumpo veikimo benzodiazepinus ir vengti tęstinio jų vartojimo. Pirmo pasirinkimo benzodiazepinai žindymo metu yra trumpai veikiantis midazolamas, vidutinio veikimo aktyvių metabolitų neturintis lorazepamas arba oksazepamas, kuris ị pieną patenka labai nedideliais kiekiais dèl savo hidrofiliniu savybių. Yra pavienių duomenų, kad benzodiazepinai sukèlè nepageidaujamų reakcijų žindomam kūdikiui, bet daugelis jų pasitaiké vartojant ilgesnio veikimo benzodiazepinus (diazepamą, klonazepama) [2,13].

Neuroleptikai. Šios grupès vaistai nèštumo metu skiriami santykinai dažnai. Jais gydomi psichoziniai sutrikimai, bipolinis sutrikimas, gydymui rezistentiška depresija. Pogimdyminis periodas didina psichikos ligų atkryčio riziką. Viena iš sunkiausių paūmèjimo apraiškų yra pogimdyminè psichozè, kurios dažnumas yra iki 2 iš 1000 gimdymų [7]. Tai ūmi psichiatrinè būklè, kuri negydoma gali komplikuotis suicidu ar infanticidu.

Neuroleptikai nèra kontraindikuotini žindymo metu. Paprastai jų RID rodiklis nedidelis, svyruoja apie kelis procen- 
tus ir duomenų apie žindymo metu kūdikiams pasireiškusi šalutini poveikị yra nedaug [18]. Daugelis pirmos kartos neuroleptikų (pavyzdžiui, haloperidolis, chlorpromazinas) i motinos pieną patenka mažomis dozėmis, jų RID dažniausiai nesiekia 10 procentų [19]. Terapinėmis dozèmis vartojant haloperidoli, jo koncentracija būna maža ir reikšmingo šalutinio poveikio žindomiems kūdikiams nekonstatuota [13].

Daugelio autorių nuomone, antros kartos neuroleptiko klozapino krūtimi maitinančios motinos neturètų vartoti dèl jo sukeliamos traukulių ir agranulocitozès rizikos [20,21]. Jei vartojamas kitas antros kartos neuroleptikas, nutraukti maitinimą krūtimi netikslinga. Šios grupès vaistų taip pat žemi RID rodikliai, ị motinos pieną patenka mažais kiekiais ir žindomiems kūdikiams pasireiškusio šalutinio poveikio nustatyta nedaug, arba jis buvo nereikšmingas. Olanzapinas laikomas saugiausiu neuroleptiku žindymo metu, todèl jei reikalingas gydymas, rekomenduojama rinktis jị. Skiriant terapines olanzapino dozes, RID siekè iki kelių procentu arba žindomo kūdikio kraujo plazmoje šio vaisto nebuvo randama. Panašias charakteristikas turi ir kitas antros kartos neuroleptikas - kvetiapinas, todèl autoriai ji taip pat pateikia kaip pirmo-antro pasirinkimo neuroleptiką žindymo metu. Duomenų apie šių dviejų neuroleptikų saugumą žindymo metu yra daugiausia $[13,21]$. Risperidonas taip pat priskiriamas prie galimų vartoti žindymo metu neuroleptikų, bet apie jo saugumą duomenų nedaug, todèl rekomenduojamas tęstinis ir atidus žindomo kūdikio stebejjimas. Duomenų apie aripiprazolo, ziprazidono, paliperidono, lurazidono saugumą žindymo metu nedaug, todèl, jei yra galimybè, žindymo metu geriau rinktis kitus vaistus. Amisulprido koncentracija motinos piene yra viena iš didžiausių tarp visų neuroleptikų, todèl kai kurie autoriai šio vaisto vartojimą vertina kaip kontraindikaciją žindymui [18].

Litis ir kiti nuotaikos stabilizatoriai. Bipoliniu sutrikimu sergančių moterų atkryčio rizika po gimdymo siekia iki 35 proc., jei jos yra gydomos, ir iki 85 proc., jei nesigydo [11]. Ligos paūmejjimas kelia riziką ne tik motinos, bet ir kūdikio sveikatai, nes manijos ar depresijos fazėje pacientè gali gausiai vartoti alkoholi ar kitas psichoaktyviąsias medžiagas, dèl blogos mitybos gali vystytis mitybos nepakankamumas, pasireikšti suicidogeniškas arba save žalojantis elgesys, dèl trumaplaikių seksualinių santykių gali didèti lytiškai plintančių ligų rizika ir pan. Litis vienas dažniausiai ir ilgiausiai skiriamų nuotaikos stabilizatorių, tačiau duomenų apie jo saugumą žindymo metu nedaug. Atkreiptinas dèmesys, kad šio vaisto terapinè ir toksinè koncentracija skiriasi nedaug, todèl ji labai lengva perdozuoti. Tyrimų duomenimis, litis patenka į motinos pieną, jo RID yra aukštas ir siekia 12-30 proc., žindomo kūdikio kraujyje ličio koncentracija gali siekti 24-74 proc. motinos kraujyje esančios ličio koncentracijos
[22]. Dèl šios priežasties daugelis autorių rekomenduoja nežindyti kūdikio, jei motina gydoma ličiu [17]. Vis tik kai kurie šaltiniai gydymo ličiu nevertina kaip absoliučios kontraindikacijos žindyti ir, esant tam tikroms sąlygoms (kai nėra gydymo alternatyvų, aptarus galimą riziką su motina ir, esant galimybei, stebint ličio koncentraciją piene), gydymą ličiu žindymo metu vertina priimtiną $[2,23]$.

Valproinès rūgšties nerekomenduojama skirti vaisingo amžiaus moterims, nes šis vaistas yra žinomas kaip aiškus teratogenas, todèl žindančios pacientės jị vartoja retai. Karbamazepinas taip pat žinomas kaip teratogenas, be to, vaisiui jis gali sukelti vitamino K nepakankamumą ir kraujavimus.

Valproinès rūgšties ir karbamazepino rekomenduojama neskirti krūtimi maitinančioms motinoms. Vis dèlto šių vaistų RID rodiklis siekia atitinkamai 1-2 proc. ir 4-6 proc., todèl jei šis gydymas buvo skirtas iki gimdymo, žindymas krūtimi nèra kontraindikuotinas $[2,17,23]$

Bendrosios rekomendacijos. Apibendrinant literatūros duomenis, galima remtis šiomis pagrindinèmis rekomendacijomis [17,24]:

- Kuo anksčiau nèštumo metu su būsima motina aptarti žindymo, vartojant konkretų vaistą, perspektyvas. Staigus vaisto keitimas nėštumo pabaigoje ar iškart po gimdymo, didina psichikos sutrikimo atkryčio riziką.

- Jei motina vartojo vaistą viso néštumo metu, dažniausiai tinkamiausia strategija būtų tęsti to paties vaisto vartojimą ir žindymo metu (vis tik yra kelios išimtys). Tuo atveju, jei kelių vaistų tikètina rizika kūdikiui yra panaši, rekomenduojama nekeisti to, kuris buvo vartotas iki žindymo.

- Jei yra galimybė, tikslinga rinktis tą vaistą, kuris vertinamas kaip turintis mažiausią riziką žindomam kūdikiui.

- Individualiai vertinti žindymo naudos ir galimos vaisto vartojimo rizikos santykị.

- Jei vaistas nekontraindikuotinas žindymo metu, dažniausiai tinkamiausia strategija būtų tęsti jo vartojimą ir žindymo metu. Motinos psichikos būklès gydymas turètų būti vertinamas kaip prioritetas, todèl jei būtina skirti vaistą, kuris yra kontraindikuotinas žindymo metu, motina turètu būti paskatinta nutraukti žindymą.

- Atkreiptinas dèmesys, kad naujagimiai, ypač neišnešioti, fiziologiškai turi mažesnes vaistų klirenso galimybes.

- Reguliariai vertinti kūdikio vystymąsi, augimą, maitinimosi ịpročius, stebėti galimų su pienu gauti vaistų šalutini poveikį.

- Motinos, kurios gauna seduojančiu poveikiu pasižyminčius vaistus, turètų būti įspètos nežindyti lovoje, nes žindymo metu gali užsnūsti ir užspausti kūdikị.

- Tikslinga skirti mažiausias efektyvias vaistų dozes, pagal galimybes vengti kelių vaistų skyrimo, laikytis nėštumo metu taikyto vaistų vartojimo režimo. 
-Psichikos sutrikimų turinčios ir krūtimi maitinančios motinos turètu greitai gauti psichologinį (psichoterapinị) gydymą, bet sunkaus psichikos sutrikimo atveju medikamentinis gydymas dažnai yra esminis gydymo komponentas.

-Atkreiptinas demesys, kad pateikiamos rekomendacijos aktualesnès tuo atveju, jei kūdikis yra sveikas. Jei kūdikis jau turi sveikatos sutrikimų ar yra neišnešiotas, sprendimas jị žindyti turètų būti itin atsakingai priimtas, ypač jei motina vartoja kelis psichotropinius vaistus vienu metu.

\section{Išvados}

Něštumas ir gimdymas didina psichikos ligų paūmėjimo riziką, todèl siekiant užtikrinti motinos ir kūdikio sveikatą bei saugumą, svarbu, kad būtų skiriamas tinkamas farmakologinis ir kompleksinis nefarmakologinis gydymas. Duomenu apie psichotropinių vaistų skyrimą žindymo metu trūksta. Vis dèlto dažnu atveju žindymo nauda nusveria galimą riziką, jei farmakologinis gydymas yra individualizuojamas, reguliariai vertinama žindomo kūdikio būklè, pacientès ir kūdikio priežiūroje sistemingai dalyvauja tarpdisciplininè specialistų komanda (psichiatras, neonatologas, akušeris, pediatras, šeimos gydytojas, klinikinis farmakologas, slaugytojas).

\section{Literatūra}

1. Global strategy for infant and young child feeding. Geneva:WHO 2003;30.

2. Larsen ER, Damkier P, Pedersen LH, Fenger-Gron J, Mikkelsen RL, Nielsen RE, et al. Use of psychotropic drugs during pregnancy and breast-feeding. Acta Psychiatr Scand Suppl 2015;(445):1-28.

https://doi.org/10.1111/acps.12479

3. Newton ER, Hale TW. Drugs in breast milk. Clin Obstet Gynecol 2015;58(4):868-84.

https://doi.org/10.1097/GRF.0000000000000142

4. Yonkers KA, Wisner KL, Stewart DE, Oberlander TF, Dell DL, Stotland N, et al. The management of depression during pregnancy: a report from the American psychiatric association and the American college of obstetricians and gynecologists. Obstet Gynecol 2009;114(3):703-13.

https://doi.org/10.1097/AOG.0b013e3181ba0632

5. Ashman SB, Dawson G, Panagiotides H, Yamada E, Wilkinson CW. Stress hormone levels of children of depressed mothers. Dev Psychopathol 2002;14(2):333-49. https://doi.org/10.1017/S0954579402002080

6. Halligan SL, Herbert J, Goodyer IM, Murray L. Exposure to postnatal depression predicts elevated cortisol in adolescent offspring. Biol Psychiatry 2004;55(4):376-81.

https://doi.org/10.1016/j.biopsych.2003.09.013

7. Robertson E, Grace S, Wallington T, Stewart DE. Antenatal risk factors for postpartum depression: a synthesis of recent literature. Gen Hosp Psychiatry 2004;26(4):289-95. https://doi.org/10.1016/j.genhosppsych.2004.02.006

8. Flynn HA, Davis M, Marcus SM, Cunningham R, Blow FC. Rates of maternal depression in pediatric emergency department and relationship to child service utilization. Gen Hosp Psychiatry 2004;26(4):316-22.

https://doi.org/10.1016/j.genhosppsych.2004.03.009

9. Grace SL, Evindar A, Stewart DE. The effect of postpartum depression on child cognitive development and behavior: a review and critical analysis of the literature. Arch Womens Ment Health 2003;6(4):263-74

https://doi.org/10.1007/s00737-003-0024-6

10. Cohen LS, Altshuler LL, Harlow BL, Nonacs R, Newport DJ, Viguera AC, et al. Relapse of major depression during pregnancy in women who maintain or discontinue antidepressant treatment. JAMA 2006;295(5):499-507.

https://doi.org/10.1001/jama.295.5.499

11. Viguera AC, Whitfield T, Baldessarini RJ, Newport DJ, Stowe Z, Reminick A, et al. Risk of recurrence in women with bipolar disorder during pregnancy: prospective study of mood stabilizer discontinuation. Am J Psychiatry 2007;164(12):1817-24.

https://doi.org/10.1176/appi.ajp.2007.06101639

12. Weissman AM, Levy BT, Hartz AJ, Bentler S, Donohue M, Ellingrod VL, et al. Pooled analysis of antidepressant levels in lactating mothers, breast milk, and nursing infants. Am J Psychiatry 2004;161(6):1066-78.

https://doi.org/10.1176/appi.ajp.161.6.1066

13. Kronenfeld N, Berlin M, Shaniv D, Berkovitch M. Use of psychotropic medications in breastfeeding women. Birth Defects Res 2017;109(12):957-97.

https://doi.org/10.1002/bdr2.1077

14. Newport DJ, Ritchie JC, Knight BT, Glover BA, Zach EB, Stowe ZN. Venlafaxine in human breast milk and nursing infant plasma: determination of exposure. J Clin Psychiatry 2009;70(9):1304-10.

https://doi.org/10.4088/JCP.08m05001

15. Orsolini L, Bellantuono C. Serotonin reuptake inhibitors and breastfeeding: a systematic review. Hum Psychopharmacol 2015;30(1):4-20.

https://doi.org/10.1002/hup.2451

16. Cuomo A, Maina G, Neal SM, De Montis G, Rosso G, Scheggi $\mathrm{S}$, et al. Using sertraline in postpartum and breastfeeding: balancing risks and benefits. Expert Opin Drug Saf 2018;17(7):719-25.

https://doi.org/10.1080/14740338.2018.1491546

17. McAllister-Williams RH, Baldwin DS, Cantwell R, Easter A, Gilvarry E, Glover V, et al. British association for psychopharmacology consensus guidance on the use of psychotropic medication preconception, in pregnancy and postpartum 2017. J Psychopharmacol Oxf Engl 2017;31(5):519-52.

https://doi.org/10.1177/0269881117699361

18. Pacchiarotti I, León-Caballero J, Murru A, Verdolini N, Furio 
MA, Pancheri C, et al. Mood stabilizers and antipsychotics during breastfeeding: focus on bipolar disorder. Eur Neuropsychopharmacol J Eur Coll Neuropsychopharmacol 2016;26(10):1562-78.

https://doi.org/10.1016/j.euroneuro.2016.08.008

19. Parikh T, Goyal D, Scarff JR, Lippmann S. Antipsychotic drugs and safety concerns for breast feeding infants. South Med J 2014;107(11):686-8.

https://doi.org/10.14423/SMJ.0000000000000190

20. National Collaborating Centre for Mental Health (UK). Antenatal and postnatal mental health: clinical management and service guidance: Updated edition [Internet]. Leicester (UK): British Psychological Society; 2014 [cited 2019 Nov 18]. (National Institute for Health and Clinical Excellence: Guidance). Available from: http://www.ncbi.nlm.nih.gov/ books/NBK305023/

21. Uguz F. Second generation antipsychotics during the lactation period: a comparative systematic review on infant safety. J Clin Psychopharmacol 2016;36(3):244-52.

https://doi.org/10.1097/JCP.0000000000000491

22. Chaudron LH, Jefferson JW. Mood stabilizers during breastfeeding: a review. J Clin Psychiatry 2000;61(2):79-90. https://doi.org/10.4088/JCP.v61n0202

23. Uguz F, Sharma V. Mood stabilizers during breastfeeding: a systematic review of the recent literature. Bipolar Disord 2016;18(4):325-33.

https://doi.org/10.1111/bdi.12398

24. Taylor D, Barnes TRE, Young AH. The Maudsley prescribing guidelines in psychiatry. Wiley Blackwell 2019:736.

\section{BREASTFEEDING AND PSYCHOTROPIC MEDICATIONS}

\section{Rutkauskas, S. Lesinskienė, N. Fatkulina}

Keywords: breast-feeding, mental illness, psychotropic drugs, antidepressants, benzodiazepines, lithium, mood stabilizers.

\section{Summary}

The article describes the main issues related to breast feeding in mothers who receive psychopharmacological treatment. The main groups of psychotropic drugs are reviewed and recommendations are provided. Many medications used to treat psychiatric conditions are considered to be safe enough to recommend that the mother continue breastfeeding despite it's regular use. It is important to encourage mothers with mental disorders to breastfeed, as it helps to maintain the mother-child bond, which is important for the healthy development of the baby. Some patients with mental illness refuse to continue breastfeeding or stop taking psychotropic drugs because of fear of harm the baby, so it is important to inform the family about potential risks and to help choose the right medication. Pregnancy and childbirth increase the risk of exacerbation of mental illness, so proper pharmacological and complex non-pharmacological treatment is important to ensure maternal and infant health. The benefits of breastfeeding outweigh potential risks if pharmacological treatment is individualized, the condition of breastfeeding baby is being regularly evaluated and interdisciplinary team of specialists (psychiatrist, neonatologist, midwife, pediatrician, family physician, clinical pharmacologist, nurse) is involved. The exacerbation of mental disorders in mothers may cause significant damage to the development of their infants, therefore it is necessary to base the decision on scientific data and correctly inform targeted population.

Correspondence to: viliui.rutkauskui@gmail.com

Gauta 2020-01-30 